\title{
IoT architecture that supports the stimulation of gross motor development in children aged 5-6 years using drop box game
}

\author{
Halim Wajdi a, Novian Anggis Suwastika ${ }^{b}$, Rahmat Yasirandi c \\ a,c Department of Informatics, Telkom University, Bandung, Indonesia \\ ${ }^{b}$ Department of Information Technology, Telkom University, Bandung, Indonesia \\ email:ahalimwajdi@student.telkomuniversity.ac.id, banggis@telkomuniversity.ac.id, cbatanganhitam@telkomuniversity.ac.id
}

\begin{tabular}{|c|c|}
\hline ARTICLE INFO & A B S T R A C T \\
\hline $\begin{array}{l}\text { Article history: } \\
\text { Received } 16 \text { May } 2020 \\
\text { Revised } 15 \text { June } 2020 \\
\text { Accepted } 29 \text { June } 2020 \\
\text { Published } 8 \text { July } 2020\end{array}$ & $\begin{array}{l}\text { Gross motor development in children influences the development of self- } \\
\text { confidence and the concept of self-formation as they mature. Many people assume } \\
\text { that gross motor development is often ruled out compared to other aspects of } \\
\text { child development because the perception of gross motor development will } \\
\text { automatically increase with age, when in fact the gross motor development must }\end{array}$ \\
\hline $\begin{array}{l}\text { Keywords: } \\
\text { drop box game } \\
\text { early childhood } \\
\text { gross motor development } \\
\text { Internet of Things } \\
\text { IoT }\end{array}$ & $\begin{array}{l}\text { continue to be stimulated so that it develops perfectly. The activity used in this } \\
\text { research is the game of putting balls into a hole by moving the game box (Drop } \\
\text { Box). This research aims to build a device that has been designed and assess the } \\
\text { ability/performance of the system based on the parameters of functionality, the } \\
\text { accuracy of values, and reading speed. In this research, the Drop Box game }\end{array}$ \\
\hline $\begin{array}{l}\text { IEEE style in citing this } \\
\text { article: } \\
\text { H. Wajdi, N. A. Suwastika } \\
\text { and R. Yasirandi, "IoT } \\
\text { architecture that supports } \\
\text { the stimulation of gross } \\
\text { motor development in } \\
\text { children aged 5-6 years } \\
\text { using drop box game," } \\
\text { Register: Jurnal Ilmiah } \\
\text { Teknologi Sistem Informasi, } \\
\text { vol. 6, no. 2, pp. 119-129, } \\
\text { 2020. }\end{array}$ & $\begin{array}{l}\text { implements Internet of Things (loT) to support recording activities and processing } \\
\text { data obtained from recording children's activities. In this research also proposed } \\
\text { a suitable IoT architecture and has been applied in the development of the Drop } \\
\text { Box game device. We carry out functional system testing and system performance } \\
\text { testing based on accuracy parameters and speed-reading parameters. The test } \\
\text { results show that the functionality of the system runs with an average of } 100 \% \text {. } \\
\text { For system performance, the result is } 86.59 \% \text { for } 20 \mathrm{~ms} \text { as the optimal delay in } \\
\text { testing accuracy and } 79 \mathrm{~ms} \text { for reading speed. }\end{array}$ \\
\hline
\end{tabular}

\section{Introduction}

Developments in the golden period of growth (0-6 years) greatly affect the human condition in the future. Motor development is one of the factors that influence human development. Motor development classified into two groups, namely gross motor development and fine motor development [1]. Gross motoric is body movements using large muscles that are affected by the child's maturity. For example, the ability to sit, kick, run, and others, on the other hand, the fine motor is a movement that uses fine muscles or certain parts of the body that are affected by the opportunity to learn and practice [1]. Motor development in children has a significant influence on their development in the future. But not many parents understand the importance of gross and fine motor development in children requires continuous training and development [2]. In general, learning or development of motor skills/movements focuses on fine motor skills.

Unfortunately, misassumptions have set aside this gross motor development. Because they assume that gross motor development automatically progresses through a child's age. There is a need to rectify such an incorrect assumption. Moreover, there is a fact that gross motor development also 
affects self-confidence and the construct of self-concept. It emphasizes that children's gross motor development is crucial as other aspects of development for the early ages [3].

In Indonesia, parents can utilize Kuesioner Pra Skrining Perkembangan (KPSP) to monitor their children's motor development, especially motor skills [1]. Such a tool made by the Ministry of Health of the Republic of Indonesia consists of questions and instructions for assessing children's development [1]. In KPSP, there are four categories of children development, namely the development of Coarse Gross Motor, Fine Motor, Speech \& Language, and Socialization \& Independence [1].

Gross motor skills consist of strength, speed, endurance, balance, flexibility, and coordination [4]. Coordination is a skill to combine or separate a complex task [4]. Based on Lopes' research, children with low coordination skills potentially have a low academic ability [5]. In a study conducted by Rigoli, the motor coordination shows an indirect impact to the academic achievement mediated by WM (Working Memory) [6]. One of the activities carried out to develop gross motor coordination of children is the activity of throwing and catching the ball. The research conducted by Erlinda concluded that the game of catching the ball can improve the gross motor coordination of child coordination [7]. In KPSP, these two activities become parameters for assessing the development of gross motor coordination in children [1]. Additional activities to catching throwing can be found in the Drop Box game [8]. Within the game, there are activities to stimulate the ability of eye and limb coordination while monitoring the children's motor development. The form of simple game play and daily-life objects involved in Drop Box activities can attract interest of the children. For instance, a child can use a game box and table tennis ball, then he/she has to place the ball in the box through any holes provided. Eyes and hands work together to control the moving tool so that the ball can go inside the box.

In the research conducted by Erlinda, data collection and processing are done manually via observation [7]. Similarly, teachers or health workers observe the child under supervision using the KPSP tool. Meanwhile, the Drop-box activities works wirelessly facilitated by the Internet of Things (IoT). It enables an automatic observation and assessment via sensor readings from the game devices. Through IoT, game objects can communicate and interact to each other enabling an automatic rating system in this game. In addition, the resulting activity data is transferable to the internet which makes it highly accessible. In this system, the teacher acts as the end-user. Prior to playing Drop-box game, he/she must introduce the rules of the game to the target player (a child). During game sessions, devices are communicating their sensor readings and continuously sending the processed data to the IoT platform. In the server-side the received data is processed again so that the teacher can easily analyze the data. Each device for this Drop-box game use NodeMCU as the microcontroller and IR Obstacle Avoidance as the sensor.

Previous studies have shown that a combination of education and IoT can help the learning process highly accessible via internet. Bagheri explained in his research that IoT can be applied in education and categorizes the application into four groups: energy management and real-time ecosystem monitoring, monitoring student health care, classroom access control, and improving teaching and learning [9]. Gòmez proposed a system that allows students to interact with physical objects around them in the virtual world representing the subject of learning to create a more significant learning space [10]. Furthermore, Pruet developed mobile learning platforms and applications for schools in rural areas to increase student involvement and learning performance [11]. Ning explained in his research that IoT involves every field in the system of science and technology and the technology covers most subjects [12]. In a study conducted by Gunasekera, it was explained that in addition to agriculture, health, industry, and home automation, IoT can be applied in the field of education especially agricultural education to produce professionals in the field of agriculture [13]. Abbasy examines the effect of IoT in top-level education and shows significant results between the relationship of IoT with top-level education in terms of learning and management, hyper-connectivity, collaboration opportunities, and research [14]. Also, the emergence of IoT has an impact on changing traditional education into a measurable education that can adapt to rapid changes [14]. Selinger explained the potential impact of IoT in the world of education which makes the mastery time of material faster, more relevant, interesting, and motivating students by connecting people, processes, data, and things [15].

IoT has led a revolution in top-level education. According to Tianbo, IoT has changed the way learning, management, research and training in schools [16]. Aldowah explained that IoT has 
tremendous potential in education, especially in higher education such as universities. Furthermore, IoT can improve learning outcomes by providing a more prosperous learning experience, increasing operational efficiency, and getting real-time insights that can be used for decision making about student learning performance [17]. Even the research conducted by Hasan combining IoT with education such as ABA (Applied Behavior Analysis) in the form of games can help developing cognitive abilities of autistic children [18].

The application of IoT to communicate sensor readings is prime for monitoring and communication (sending data) [19, 20, 21, 22, 23]. In previous studies, a combination of the IoT paradigm with games to build blocks can detect early motor disturbances in children called Smart Cube [23]. Tests for Drop Box game activities have been carried out to identify the suitability of system functionality and analyzing system performance based on the scoring accuracy and reading speed of the system when the ball enters a hole.

\section{Research methods}

Figure 1 shows the research procedures in correspondence with Drop Box game application. The study begins with a literature review about gross motor and the IoT. The subsequent step is designing the Drop Box game system architecture which consists of system concepts, game device design, game activities, hardware design, software design, and data communication on the Drop Box game system. The following step is the testing phase with 3 scenarios which include functionality test, scoring accuracy test, and sensor reading speed test.

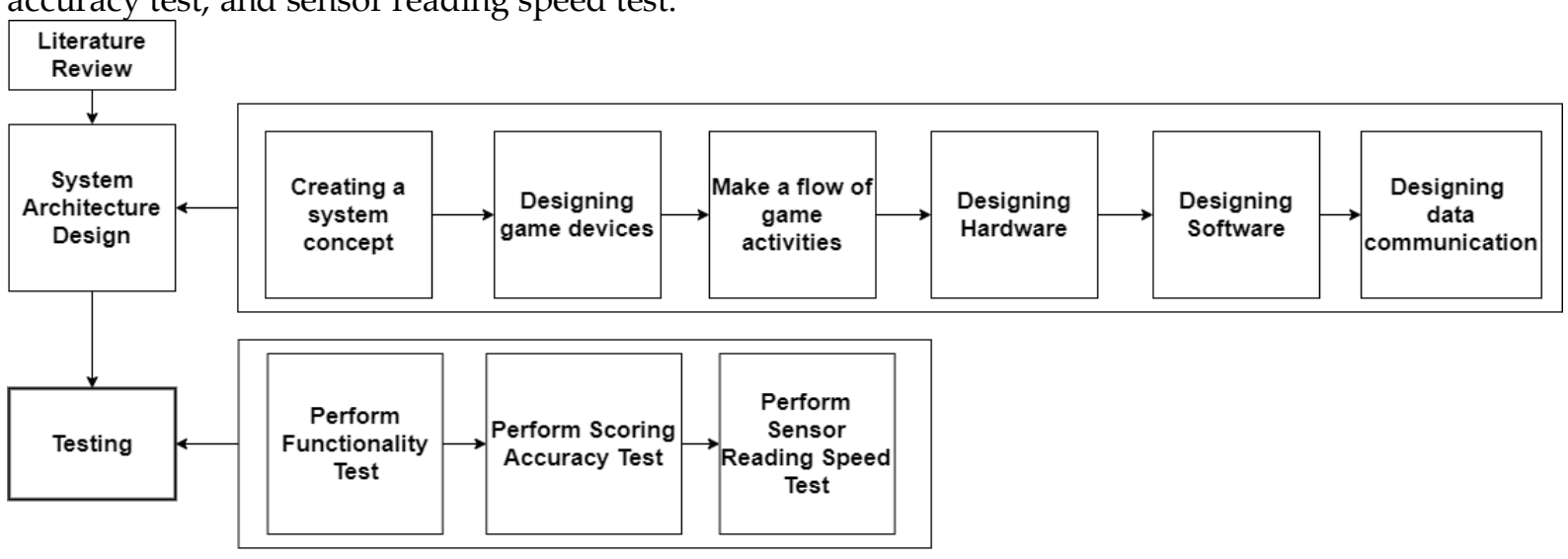

Figure 1. Research method flow

\subsection{System concept}

Here is an overview of the IoT architecture and the concept of the system built for the Drop Box game:

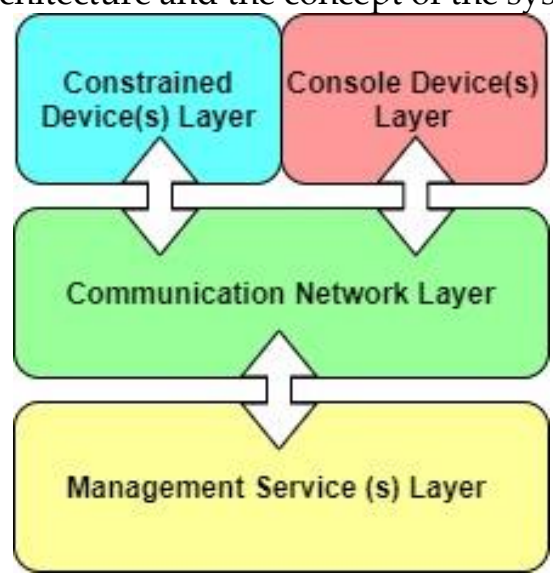

Figure 2. IoT architecture for the proposed education games

Figure 2 explains the description of the IoT architecture for the educational games proposed in this research. Constrained Device(s) Layer is a layer that contains hardware devices that are located/embedded/installed on a game device, in this regard are the sensors, microcontrollers, and PCs. Console Device(s) Layer is the user-side device to display the results of data management performed at the service layer management. The corresponding devices at this layer could be smartphones, laptops, PCs, and others. 
Communication Network Layer is responsible for the communication between Constrained Devices, Console Devices and Management Service layers. Management Service Layer stores the data and handles all transactions in the system. This may involve Analytical Platforms, Data management, Security management, and information system integration. In this research, the Management Service Layer is facilitated by an IoT platform called Thingspeak.

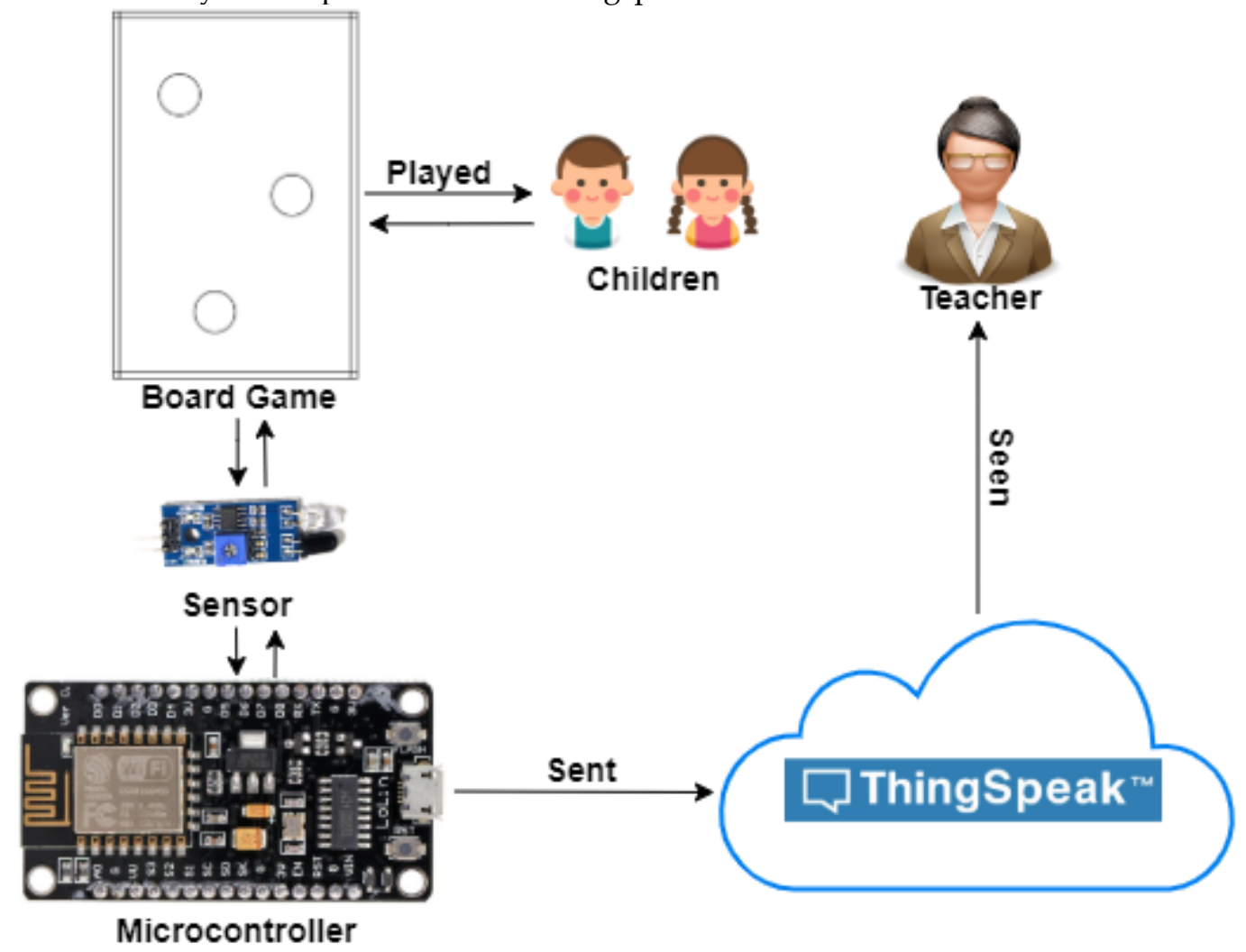

Figure 3. The concept of the system in the game Drop Box

Figure 3 explains how the architecture of the Drop Box game that applies an IoT architecture. In the diagram, the log of children's activities when playing the game Drop Box is sent to the cloud for processing and storage. Similarly, Gunasekera applied Thingspeak platform for agricultural education [14]. Through a PC or mobile device, the teacher can display the results of data processing obtained from gaming activities to determine the child's gross motor development specifically the ability to coordinate eyes and limbs.

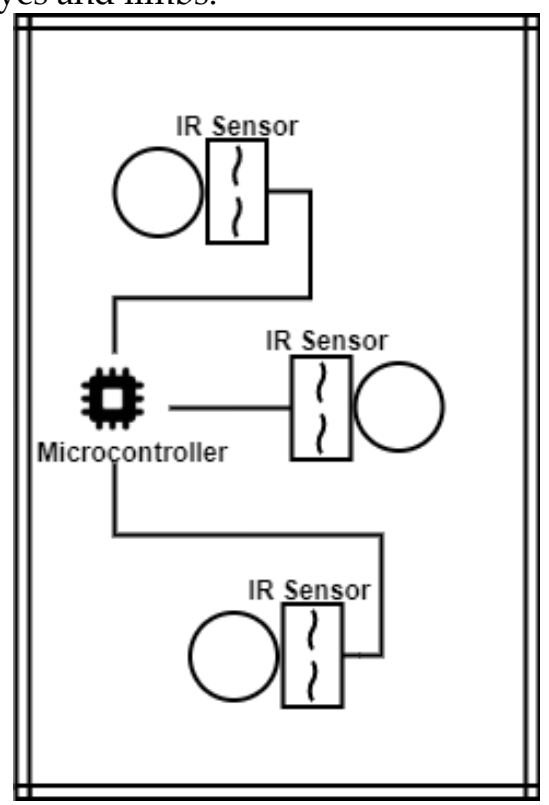

(a)

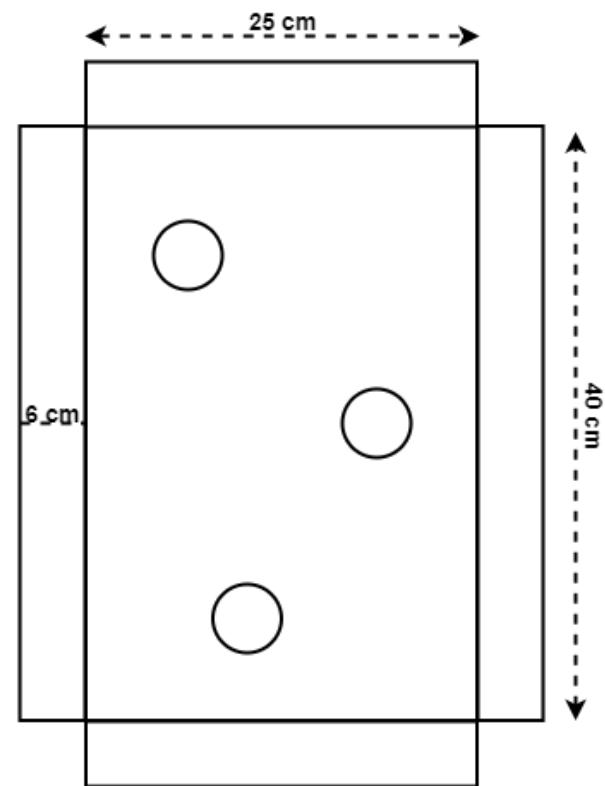

(b)

Figure 4. (a) Bottom view of game devices and (b) Top view of game devices 


\subsection{Game device design}

Figure 4(a) and Figure 4(b) illustrate the design of game devices. Every hole in the game box is mounted with an infrared sensor to detect if the ball has entered the hole. Each sensor installed is connected to a microcontroller installed inside the game box. Both sensors and microcontroller are installed at the bottom of the game box. The box should appear as a picture canvas, then it is called as game arena. It has three holes that serve as the entry point for the ball. The dimension of rectangular-shaped box is 40 $\mathrm{cm} \times 25 \mathrm{~cm} \times 6 \mathrm{~cm}$ of length, width and height, respectively. The sides of the game arena has boundaries. And each hole has a diameter of $5 \mathrm{~cm}$. The Drop Box game requires a ping pong ball with $4 \mathrm{~cm}$ diameter.

\subsection{Game activity flow}

Drop Box game has a mission that the child must fulfil. The mission is to make the ball enters the game box through a hole provided. Figure 5 explains the game flow in Drop Box game. It starts by laying the ball on the surface of the game box. Then, the child must hold the game box up that triggers the timer to start counting down. During this game session, he/she must move the game box to any direction carefully (due to the lightness of the ping pong ball). The movement of the box should navigate the ball to enter a hole. There is a possibility that the ball got out the game arena before entering a hole. If this happens, he/she can respawn the ball on the game box. If the ball enters a hole before the time is up, the game outputs a sound effect (buzzer) and add an additional score to the corresponding hole. Whenever the timer reaches zero, the Drop Box game ends.

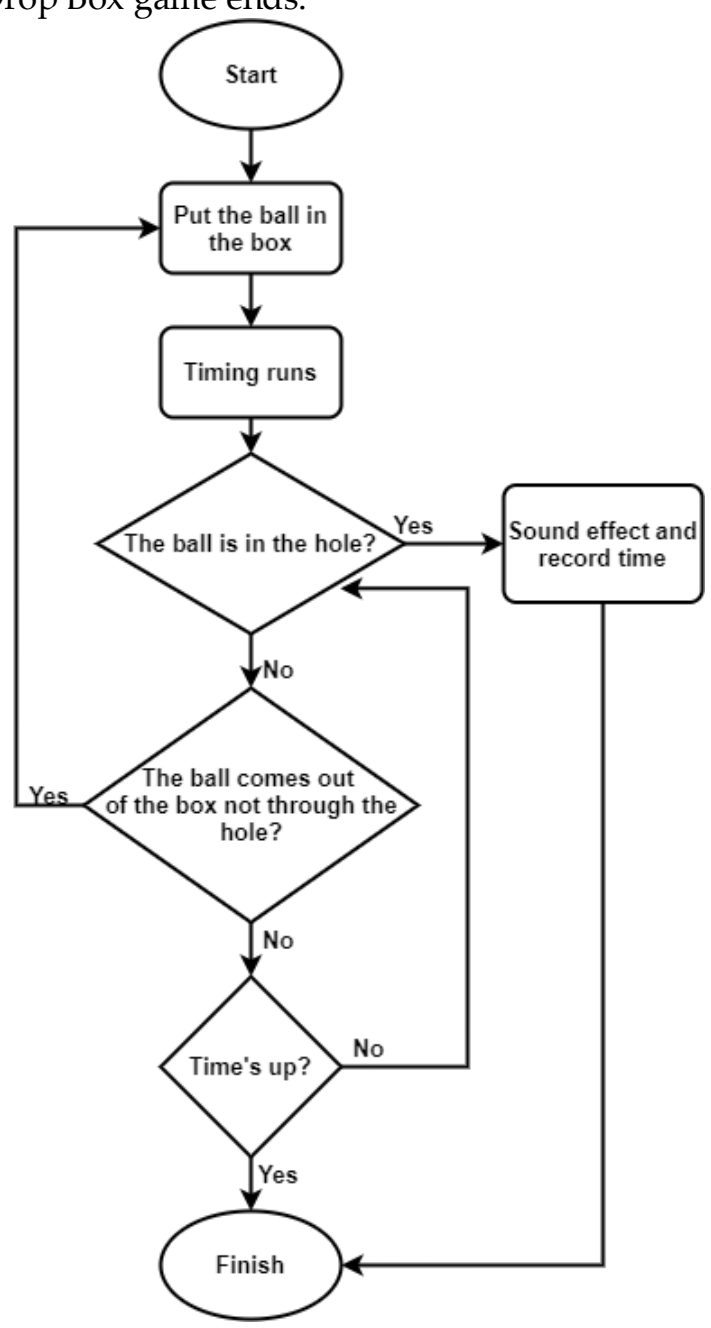

Figure 5. Game activity flow

\subsection{Hardware design}

The hardware design used in this system can be seen in Figure 6. Figure 6 illustrates the hardware design that is applied to the Drop Box game. In this system, three IR obstacle avoidance sensors, 3 buzzers, and a NodeMCU ESP-8266 are used. Each sensor is connected to the microcontroller and placed in the inner side of each hole of the game board to detect the ball entrance. Then, three buzzers are 
indicators for the first, second, and third holes are also connected to the microcontroller. In addition, to make the hardware system runs, a battery or a DC power supply should be connected appropriately.

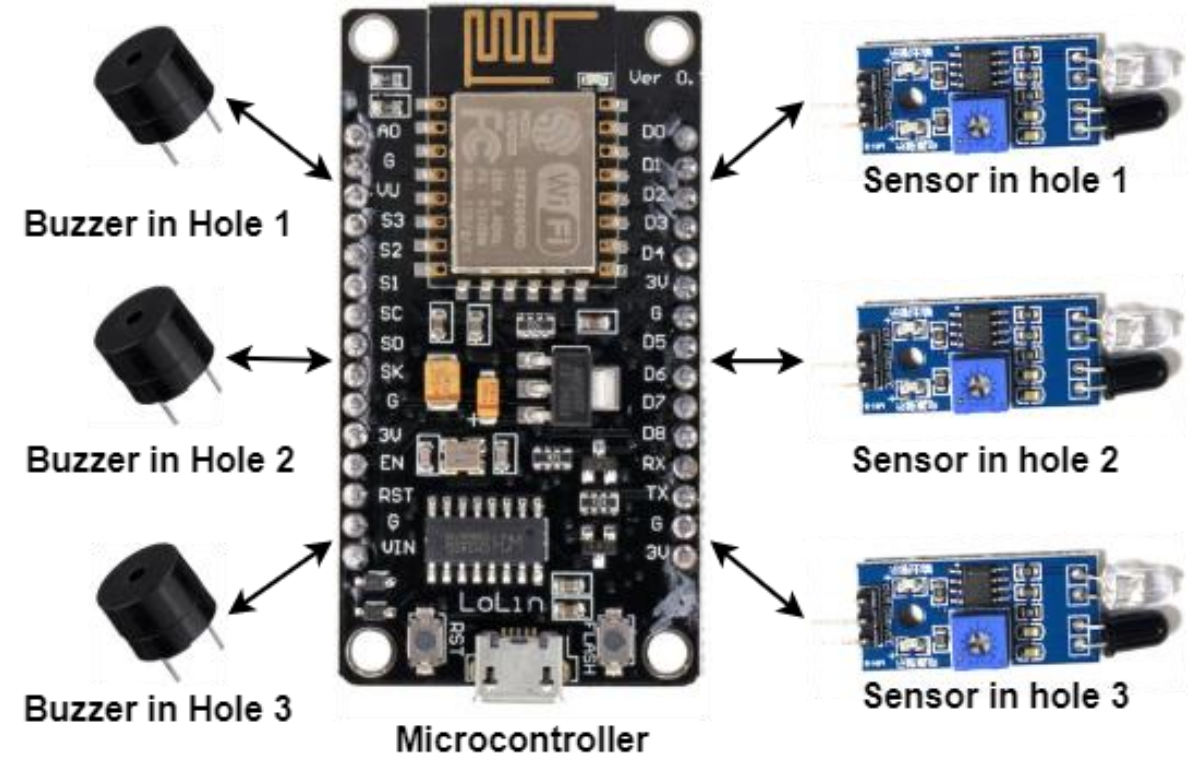

Figure 6. Tools and devices used

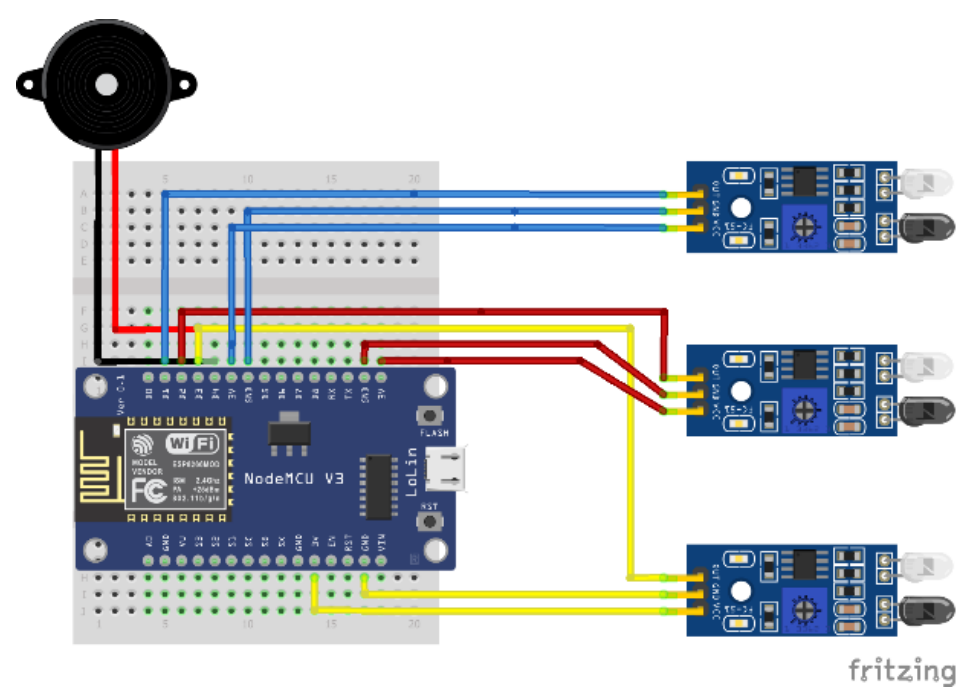

Figure 7. Wiring diagram for Drop Box game hardwares

Figure 7 illustrates the wiring of each IR module to the microcontroller. The blue cable connects the NodeMCU ESP-8266 with the first sensor, the red connects the second sensor and the yellow color connects the third sensor with the NodeMCU ESP-8266.

\subsection{Software design}

Figure 8 illustrates the flowchart of the Drop Box game. Each sensor continuously reads ball entrance. If the ball enters the hole, the count of the corresponding hole increases by one. The program finishes when the predetermined time runs out and the program stops automatically. The time can be adjusted according to the level of difficulty desired by the teacher in conducting the test (for example 3 minutes, 5 minutes, or 10 minutes). At the end of the game, the final result/total score is stored in the microcontroller for transfer to the cloud.

\subsection{Data communication flow}

Figure 9 illustrates the flow of data communication that occurs in the system. The sensor produces binary values: HIGH (if there are no objects in the sensor range) and LOW (if there are objects in the sensor range). Then, it is forwarded to the microcontroller to process the data obtained as the number of balls detected in each sensor. The accumulated sensor reading from each hole is then sent to 
Thingspeak. Finally, it stores the results (scores) as the number of balls entering through the first, second, third hole, and the total score of corresponding game session.

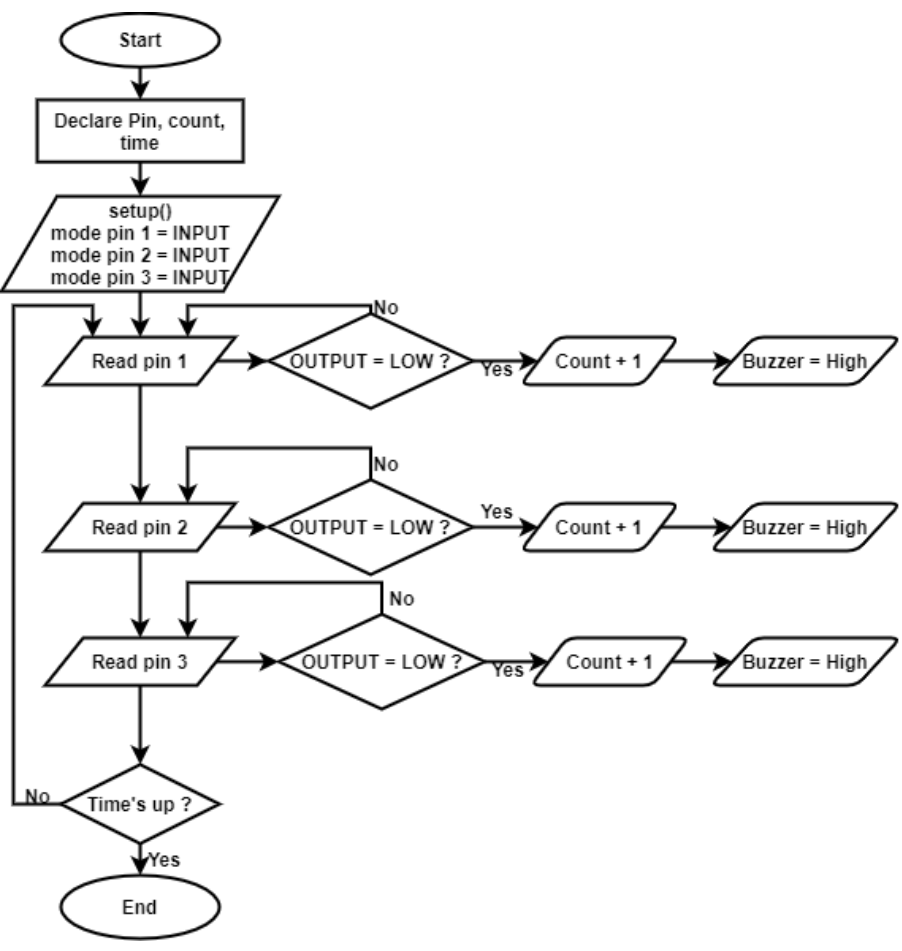

Figure 8. Drop Box game flowhart

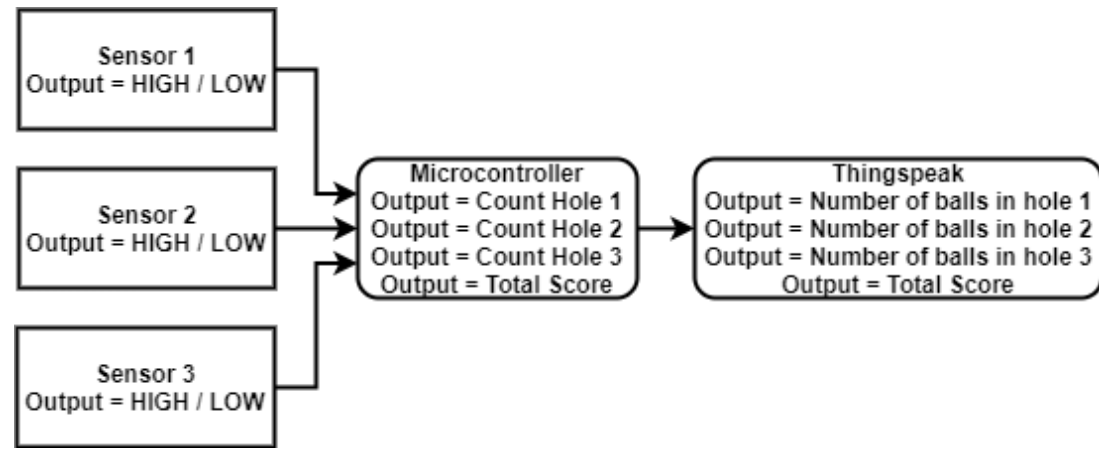

Figure 9. Data communication flow

\subsection{Testing scenarios}

The test scenarios for Drop Box game consists of Functionality, Accuracy, and Sensor Reading Speed.

1. Functionality Test evaluates how well the designated functionality runs in the Drop Box game components and devices. For this case there are no irregularities or discrepancies detected by the system. For example, if the ball got out of the game arena and the child inserted the ball into the hole by hand, etc.

2. Scoring Accuracy Test compares the actual balls entering a hole to the system-detected ball entrance.

3. Sensor Reading Speed Test measures the reading speed of the game device. This test is done by comparing the time the sensor does not detect anything with the time when the sensor detects the ball entering the hole. By comparing this, the difference is obtained, which can be concluded that the difference is the speed of reading the device.

\section{Result and Discussion}

\subsection{Game box prototype}

Figure 10(a) and Figure 10(b) illustrate the prototype of the Drop Box game that was created in accordance with the game design. 


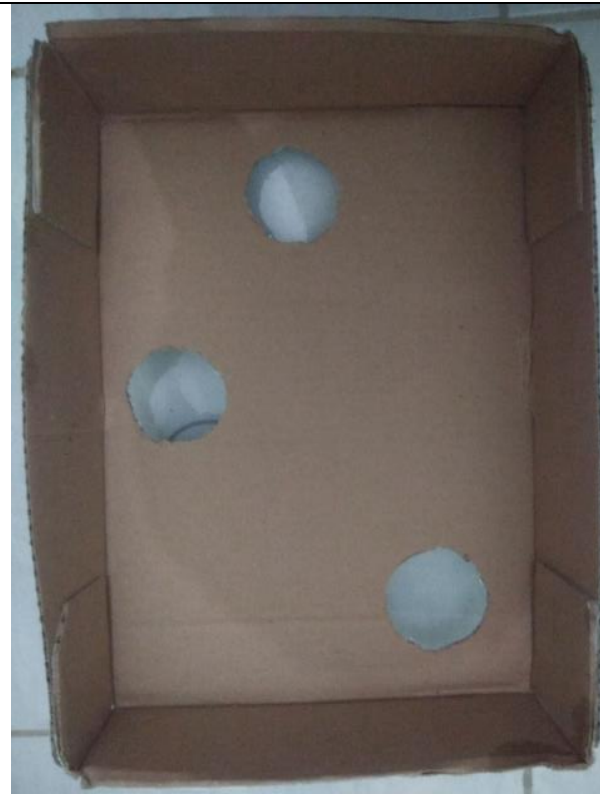

(a)

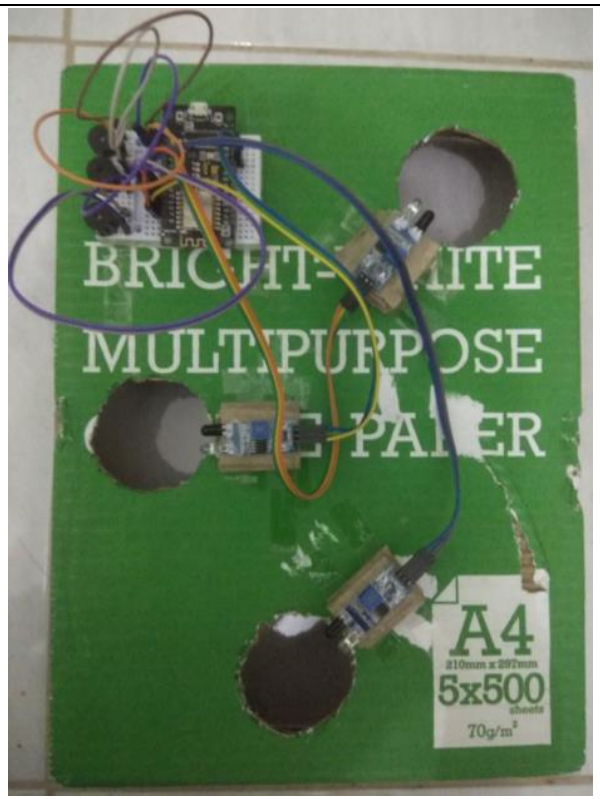

(b)

Figure 10. (a) Display prototype from above and (b) Display prototype from the bottom

\begin{tabular}{|c|c|c|c|}
\hline ( & - & $\square$ & $x$ \\
\hline & & & Send \\
\hline $16: 35: 22.947 \rightarrow$ Sensor 2 : Bola Masuk & & & $\wedge$ \\
\hline $16: 35: 30.339 \Rightarrow$ Sensor 2 : Bola Masuk & & & \\
\hline 16:35:33.558 $\rightarrow$ Sensor 3 : Bola Masuk & & & \\
\hline $16: 35: 37.090 \rightarrow$ Sensor 1 : Bola Masuk & & & \\
\hline $16: 35: 40.468 \rightarrow$ Sensor 2 : Bola Masuk & & & \\
\hline $16: 35: 40.535 \rightarrow$ Sensor 2 : Bola Masuk & & & \\
\hline 16:35:49.369 $\rightarrow$ Sensor 1 : Bola Masuk & & & \\
\hline $16: 35: 49.436$-> Sensor 1 : Bola Masuk & & & \\
\hline $16: 35: 52.665$-> Sensor 1 : Bola Masuk & & & \\
\hline $16: 35: 58.723 \rightarrow$ Sensor 3 : Bola Masuk & & & \\
\hline $16: 35: 58.825 \rightarrow$ Bola di Lubang $1: 5$ & & & \\
\hline $16: 35: 58.825 \rightarrow$ Bola di Lubang $2: 6$ & & & \\
\hline $16: 35: 58.859 \rightarrow$ Bola di Lubang $3: 3$ & & & \\
\hline $16: 35: 58.859$-> Totat Skor: 14 & & & $v$ \\
\hline$\square$ Autoscroll $\square$ Show timestamp & 9600 baud & $v$ & Clear outpu \\
\hline
\end{tabular}

(a)

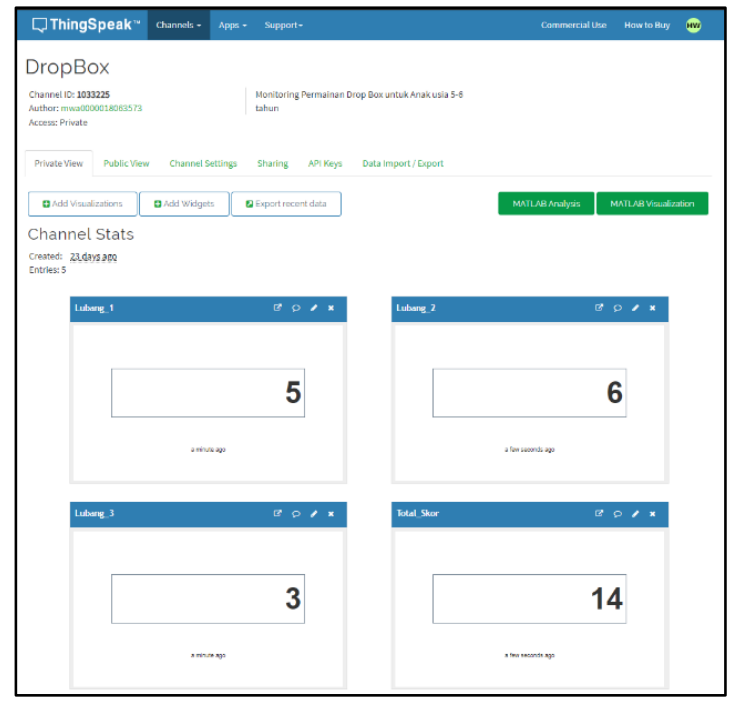

(b)

Figure 11. (a) Output serial monitor Arduino IDE and (b) Display results on thingspeak

Table 1. Functionality test

\begin{tabular}{llc}
\hline \multicolumn{1}{c}{ Component } & \multicolumn{1}{c}{ Successful Parameters } & Results \\
\hline Microcontroller & $\begin{array}{l}\text { 1. Connectable to a computer using a USB Cable } \\
\text { 2. Reprogrammable. }\end{array}$ & $100 \%$ \\
& $\begin{array}{l}\text { 3. Connected to the internet. } \\
\text { IR Obstacle Avoidance Sensor }\end{array}$ & $100 \%$ \\
& $\begin{array}{l}\text { 1. Detects object in range. } \\
\text { 2. Send reading to the microcontroller. }\end{array}$ & $100 \%$ \\
Buzzer & Sounds as configured by the frequency & $100 \%$ \\
Drop Box game & 1. Detect ball entrance through hole. & \\
& 2. Accumulates balls entering each hole. & \\
& 3. Counting down accurately. & \\
& 4. Able to show the final results. & \\
\hline
\end{tabular}

In Figure 11(a) we can see the output of the serial monitor on Arduino IDE with the results of 5 balls in hole 1, 6 balls in hole 2, 3 balls in hole 3, and a total score of 14 balls. In Figure 11(b) we can see 
the results at Thingspeak with the same results as the results in the serial monitor, namely 5 balls in hole 1,6 balls in hole 2,3 balls in hole 3 , and a total score of 14 balls.

\subsection{Functionality test result}

The results of functionality testing can be seen in Table 1 . Each component and game device were tested for its functionality. Each component and game device has functioned properly based on predetermined parameters as evidenced by the results of testing the functionality in Table 1.

\subsection{Scoring accuracy test result}

The scoring accuracy test is done by adjusting the delay in the program to find the most optimal delay for use in the game Drop Box. Delays experimented in this test were $15 \mathrm{~ms}, 17 \mathrm{~ms}, 20 \mathrm{~ms}, 23 \mathrm{~ms}$, and 25 $\mathrm{ms}$. The results of testing the scoring accuracy is shown in Table 2.

Each delay was tested 5 times each. From the test results the delay affects quite significantly to the scoring of the game. Table 2 emphasize the most optimal delay for the Drop Box game is $20 \mathrm{~ms}$. Scoring error such found in this game is due to double reading when the ball passes the IR sensor. In the table, the smaller the delay the more frequent double readings, and vice versa. Ten additional test using the $20 \mathrm{~ms}$ delay improved the accuracy to a maximum $92.5 \%$ and minimum $86.3 \%$.

Table 2. Scoring accuracy based on delay

\begin{tabular}{cccc}
\hline Delay(ms) & Total Ball & Actual Results & Average \\
\hline 15 & 98 & 62 & $63.26 \%$ \\
17 & 106 & 89 & $83.96 \%$ \\
20 & 97 & 84 & $86.59 \%$ \\
23 & 104 & 85 & $81.73 \%$ \\
25 & 103 & 73 & $70.87 \%$ \\
\hline
\end{tabular}

\subsection{Reading speed test result}

In this test, the optimal delay was used. Table 3 shows the average speed of the sensor readings.

\begin{tabular}{ccc}
\multicolumn{3}{c}{ Table 3} \\
\hline Testing & Reading speed Drop Box game \\
\hline 1 & $00: 00: 00.078$ & Average \\
2 & $00: 00: 00.080$ & \\
3 & $00: 00: 00.085$ & $00: 00: 00.079$ \\
4 & $00: 00: 00.075$ & \\
5 & $00: 00: 00.079$ & \\
\hline
\end{tabular}

This test was carried out 5 times as shown in Table 3 reaching an average sensor reading speed of $79 \mathrm{~ms}$. This result shows that the sensor used in the game is sufficient to provide the prompt reading of ball going through a hole.

\section{Conclusions}

Three tests have been carried out for the Drop Box Game including the functionality, scoring accuracy and sensor reading speed. Based on testing result, Drop Box game systems based on IoT functionality can fully operating as expected. The overall performance test results are satisfactory indicated by scoring accuracy above $86 \%$. As such performance was achieved when the system delay was set to 20 $\mathrm{ms}$ and resulting an average sensor reading speed around $79 \mathrm{~ms}$. It can be concluded that IoT architecture can be applied to various types of children's games and with the overall value obtained from the implementation. The Drop Box game can become an alternative method/media for teachers and medical staff to assess and stimulate the development of gross motor skills of children, especially coordination. Assessment is available from the data stored in the cloud, while the development of gross motor skills occurs when the child is playing Drop Box Game. The implementation of IoT in this game makes data collection and presentation are seamless. However, this game was still lacking in accurate scoring ability. This can be caused by the sensor design to detect the ball entrance. An open challenge to improve the entrance detection by using a pair of sensors in each hole. One sensor to trigger a ball is about to enter the hole. And the other one is positioned such that the distance is just about the size of the ball. This indicating that the ball has fully entering the hole. Thus, one score can accurately made 
when both sensors are triggered sequentially. Additional research can be carried out to human test on children aged 5-6 years to see the effect of the Drop Box game system in stimulating the development of gross motoric children. in the future, IoT architecture in this research can be used to create educational or therapy tools for people with disabilities.

\section{Acknowledgement}

We would like to express our gratitude to Telkom University for funding this research.

\section{References}

[1] K. K. RI, Pedoman pelaksanaan stimulasi, deteksi, dan intervensi dini tumbuh kembang anak, Jakarta: Kementrian Kesehatan RI, 2016.

[2] L. Lismadiana, "Peran Perkembangan Motorik pada Anak Usia Dini," Jurnal Ilmiah Keolahragaan, 2013.

[3] O. Rombot, "The Application of Traditional Games to Develop Social and Gross Motor Skills in 67 Year-old Children," in International Symposium on Educational Technology (ISET), Hong Kong, 2017.

[4] T. C. Mutohir, Perkembangan Motorik pada Masa Anak-Anak, Jakarta: Proyek Pengembangan dan Keserasian Kebijakan Olahraga, Direktorat Jenderal Olahraga, Depdikanas, 2004.

[5] L. Lopes, R. Santos, B. Pereira and V. P. Lopes, "Associations between gross Motor Coordination and Academic Achievement in elementary school children," Human Movement Science, vol. 32, no. 1, pp. 9-20, 2013.

[6] D. Rigoli, J. P. Piek, R. Kane and J. Oosterlaan, "Motor coordination, working memory, and academic achievement in a normative adolescent sample: Testing a mediation model," Archives of Clinical Neuropsychology, vol. 27, no. 7, p. 766-780, 2012.

[7] E. Erlinda, I. W. Dharmayana and N. Syam, "Pengembangan Motorik Kasar Anak Usia Dini Melalui Permainan Melempar Dan Menangkap Bola," Universitas Bengkulu, Bengkulu, Indonesia, 2014.

[8] D. J. Stewart, "A DIY drop box game is a great way to build teamwork and critical thinking!," Teach Preschool, 1 November 2017. [Online]. Available: https://teachpreschool.org/2017/11/01/diy-dropbox-game/. [Accessed 7 July 2020].

[9] M. Bagheri and S. H. Movahed, "The Effect of the Internet of Things (IoT) on Education Business Model," in 12th International Conference on Signal-Image Technology \& Internet-Based Systems (SITIS), Naples, 2016.

[10] J. Gómez, J. F. Huete, O. Hoyos, L. Perez and D. Grigori, "Interaction System based on Internet of Things as Support for Education," in Procedia Computer Science, 2013.

[11] P. Pruet, C. S. Ang, D. Farzin and N. Chaiwut, "Exploring the Internet of "Educational Things"(IoET) in rural underprivileged areas," in 12th International Conference on Electrical Engineering/Electronics, Computer, Telecommunications and Information Technology (ECTI-CON), Hua Hin, 2015.

[12] H. Ning and S. Hu, "Technology classification, industry, and education for Future Internet of Things," International Journal of Communication Systems, vol. 25, no. 9 Special Issue: Internet of Things, pp. 1230-1241, 2012.

[13] K. Gunasekera, A. N. Borrero, F. Vasuian and K. P. Bryceson, "Experiences in building an IoT infrastructure for agriculture education," in Procedia Computer Science, 2018.

[14] M. B. Abbasy and E. V. Quesada, "Predictable Influence of IoT (Internet of Things) in the Higher Education," International Journal of Information and Education Technology, vol. 7, no. 12, pp. 914-920, 2017.

[15] M. Selinger, A. Sepulveda and J. Buchan, Education and the Internet of Everything How Ubiquitous Connectedness Can Help Transform Pedagogy, San Jose, CA: cisco, 2013. 
[16] Z. Tianbo, "The Internet of Things Promoting Higher Education Revolution," in Fourth International Conference on Multimedia Information Networking and Security, Nanjing, 2012.

[17] H. Aldowah, S. U. Rehman, S. Ghazal and I. N. Umar, "Internet of Things in Higher Education: A Study on Future Learning," IOP Conf. Series: Journal of Physics: Conf. Series, vol. 892, 2017.

[18] U. Hasan, M. F. Islam, M. N. Islam, S. B. Zaman, S. T. Anuva, F. I. Emu and T. Zaki, "Towards Developing an IoT Based Gaming Application for Improving Cognitive Skills of Autistic Kids," in Intelligent Information and Database Systems (ACIIDS), Singapore, 2020.

[19] J. A. Stankovic, "Research Directions for the Internet of Things," IEEE Internet of Things Journal, vol. 1, no. 1, pp. 3-9, 2014.

[20] Y. Chen, "Challenges and opportunities of internet of things," in 17th Asia and South Pacific Design Automation Conference, Sydney, NSW, 2012.

[21] S. Li, L. D. Xu and S. Zhao, "5G Internet of Things: A survey," Journal of Industrial Information Integration, vol. 10, pp. 1-9, 2018.

[22] R. Mahmoud, T. Yousuf, F. Aloul and I. Zualkernan, "Internet of things (IoT) security: Current status, challenges and prospective measures," in 10th International Conference for Internet Technology and Secured Transactions (ICITST), London, 2015.

[23] M. L. Martin-Ruiz, M. A. Valero, M. Linden, S. Nunez-Nagy and A. G. Garcia, "Foundations of a Smart Toy Development for the Early Detection of Motoric Impairments at Childhood," International Journal of Pediatric Research, vol. 1, 2015. 